\title{
Improving the topology of CAD models in the context of their susceptibility to design changes - phase of changes implementation. Part 2
}

\author{
Doskonalenie topologii modeli CAD w kontekście ich podatności \\ na zmiany konstrukcyjne - etap wprowadzania zmian. Część 2
}

\section{GRZEGORZ ŚWIACZNY MAREK WYLEŻO $*$}

DOI: https://doi.org/10.17814/mechanik.2020.10.17
The article presents the importance of effective use of CAx class systems in the design of elements made of plastic. An example of the process of creating such an element - a rear car reflex lamp - is described. The $1^{\text {st }}$ part of the article (Mechanik, 8-9/2020: 53-59) was focused on showing the individual phases of preparing a 3D model of the reflex lamp. This part of the article presents modification of the model. The authors pay special attention to the role of the tree of the 3D model structure, which is a key factor influencing the project timing.

KEYWORDS: topology of CAD model, injection technology, plastics, automotive industry, CATIA v5

Przedstawiono wagę efektywnego wykorzystania systemów klasy CAx podczas projektowania elementów z tworzywa sztucznego. Opisano proces tworzenia takiego elementu - na przykładzie tylnego odblasku samochodowego. W części 1 artykułu (Mechanik, 8-9/2020: 53-59) zaprezentowano poszczególne fazy przygotowania modelu 3D odblasku. W części 2 zostanie opisany proces modyfikacji tego modelu. Autorzy zwracają uwagę na rolę drzewa struktury modelu 3D, będącego kluczowym czynnikiem wpływającym na czas realizacji projektu.

SŁOWA KLUCZOWE: topologia modelu CAD, technologia wtrysku, tworzywa sztuczne, przemysł samochodowy, CATIA v5

\section{Wprowadzenie}

W pierwszej części artykułu [1] przedstawiono proces projektowania tylnego odblasku samochodowego. Wspomniano wówczas, że aby ograniczyć ryzyko implementacji błędnych danych wejściowych, konstruktor analizuje je pod katem wykonalności i w razie potrzeby - modyfikuje. Jednak brak technologiczności danych wejściowych nie jest jedyną sytuacją, w której mogą one być zmieniane. Zdarza się, że podczas projektowania elementu odbiorca dostarcza kolejne wersje powierzchni $A$, oczekując jak najszybszej ich implementacji w aktualnej konstrukcji modelu 3D. Sytuacja ta może się zdarzyć na każdym etapie tworzenia elementu.

\section{Proces modyfikacji tylnego odblasku samochodowego}

Konstruktor powinien być przygotowany na zmianę danych wejściowych, a co za tym idzie - geometrii całego elementu, który musi pozostawać w takich samych relacjach geometrycznych do tych danych, niezależnie od ich zmiany. Ujawnia się tutaj ogromne znaczenie sposobu tworzenia modelu 3D. Jego struktura powinna być prosta, przejrzysta i dobrze zorganizowana. Relacje geometryczne powinny być tak przemyślane, aby podmiana danych wejściowych pociągała za sobą aktualizację geometrii elementu, a jednocześnie nie komplikowała nadmiernie całej struktury. Jest to o tyle istotne, że często model 3D jednego elementu nie jest tworzony przez jednego konstruktora. Ujednolicenie zasad i nawyków przy tworzeniu struktury jest kluczowym czynnikiem wpływającym na czas realizacji całego projektu.

Wracając do opisywanego w pierwszej części artykułu odblasku samochodowego, na kolejnym etapie jego projektowania końcowa postać geometryczna zostaje wysłana do odbiorcy w celu weryfikacji oraz przygotowania struktury geometrycznej (bryły) zderzaka w rozpatrywanym rejonie. Okazuje się, że dla odbiorcy na tym etapie role danych wejściowych odwracają się i to odblask staje się źródłem płatów powierzchni i innych elementów struktury przygotowywanego zderzaka.

Model 3D zderzaka pokazano na rys. 1 . Odbiorca na podstawie otrzymanego modelu odblasku dostosował rejony mocowań oraz ustaleń, stosując wcześniej opisane zasady dotyczące wykorzystania danych wejściowych (rys. 2).

Aby zasymulować typową zmianę podczas projektowania, wprowadzono nowe, różniące się od pierwotnych, powierzchnie $A$ soczewki i zderzaka tylnego. Różnice między pierwotnymi (kolor różowy) a nowymi (kolor zielony) danymi wejściowymi widać na rys. 3.

Warto, przynajmniej w ogólny sposób, przedstawić kilka informacji na temat sposobu definiowania powierzchni w środowisku CAx.

\footnotetext{
* Mgr inż. Grzegorz Świaczny, grzegorz.swiaczny@gmail.com, Polska

Dr hab. inż. Marek Wyleżoł, prof. PŚ, marek.wylezol@polsl.pl, https://orcid.org/0000-0001-6324-510X - Politechnika Śląska, Gliwice, Polska
} 


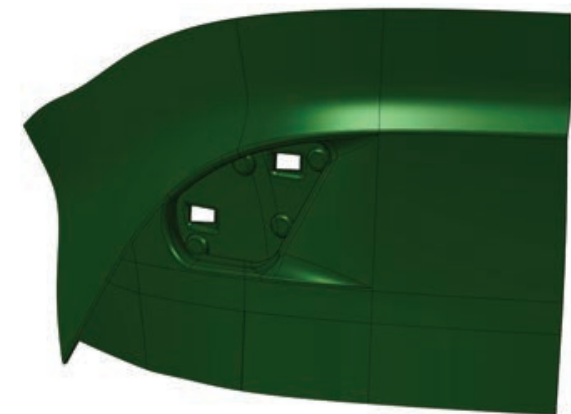

Fig. 1. Geometric form of the rear bumper in the area of the reflex lamp

Rys. 1. Postać geometryczna zderzaka tylnego w rejonie odblasku

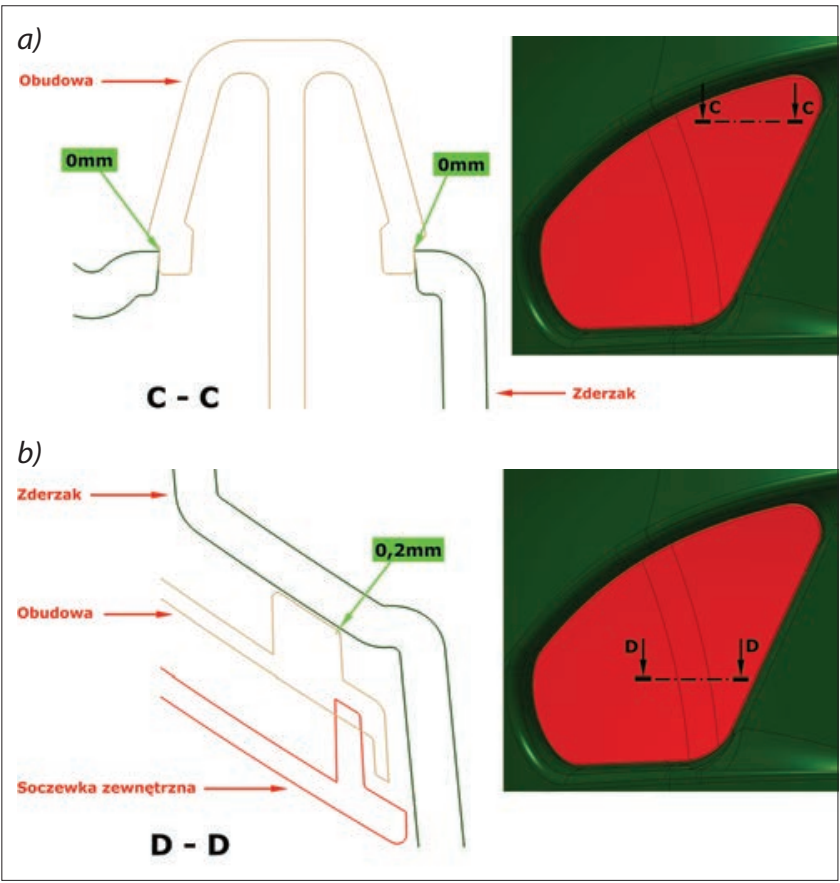

Fig. 2. Bumper areas adapted to the proposed clips and fixing pins of the reflex lamp housing: $a$ ) upper clip area, $b$ ) lower locating pin area Rys. 2. Rejony zderzaka dopasowane do zaproponowanych klipsów i pinów ustalających obudowy odblasku: a) rejon górnego klipsa, b) rejon dolnego pina ustalającego

W zaawansowanych systemach klasy CAx model powierzchni jest kontrolowany przez Konstruktora za pomoca cech konstrukcyjnych (typ cechy, jej parametry liczbowe lub wymiarowe, warunki brzegowe) [2]. Należy jednak pamiętać, że wszystkie cechy konstrukcyjne, na które konstruktor ma wpływ podczas tworzenia powierzchni, wchodzą w skład modelu matematycznego, który w jednoznaczny sposób definiuje te cechy oraz pozostałe cechy matematyczne, na które konstruktor nie ma już wpływu. Z tworzeniem powierzchni (oraz krzywych) nierozerwalnie wiąże się pojęcie ciągłości geometrycznej, jako podstawowe kryterium ich jakości.

Model powierzchniowy części można analizować pod katem różnych rodzajów ciagłości:

- Ciagłość geometryczna (G0): dwie powierzchnie maja wspólna krawędź i ponadto w obszarze „wspólnym” nie ma żadnych szczelin.

- Ciagłość styczności (G1): dwie powierzchnie ciagłe według kryterium GO maja zgodne kierunki styczne w każdym punkcie wspólnej krawędzi.

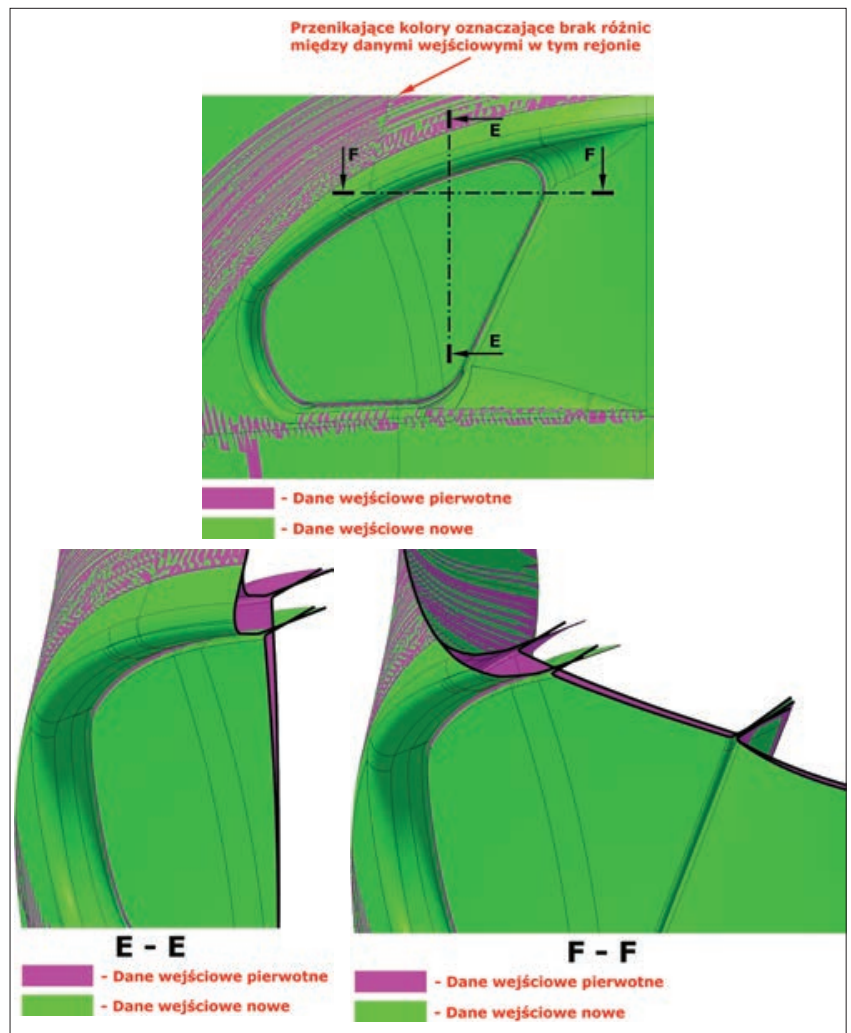

Fig. 3. Differences between primary (pink) and new (green) input data Rys. 3. Różnice między pierwotnymi (kolor różowy) a nowymi (kolor zielony) danymi wejściowymi

- Ciagłość krzywizny (G2): dwie powierzchnie ciagłe według kryterium G1 mają taki sam promień krzywizny w każdym punkcie wspólnej krawędzi.

- Ciagłość zmian krzywizny (G3): dwie powierzchnie ciagłe według kryterium G2 maja w obszarach przyległych do wspólnej krawędzi podobny i równomierny charakter zmian (gradient) krzywizny [2].

Jeśli przyjąć, że dwie powierzchnie o wspólnej krawędzi i określonej ciągłości to tzw. powierzchnie elementarne, to rozpatrywane $\mathrm{w}$ tym artykule dane wejściowe należy rozumieć jako zestaw wzajemnie powiązanych powierzchni elementarnych o własnych parametrach i równaniach matematycznych, a także różnym rodzaju ciągłości. Oznacza to, że zestaw wzajemnie powiązanych powierzchni elementarnych nie musi mieć jednego rodzaju ciagłości. W przemyśle samochodowym tzw. powierzchnie stylistyczne (widoczne), np. karoserii samochodowej, najczęściej występują pod postacią zestawów wzajemnie powiązanych powierzchni elementarnych o ciągłości G1, G2 i G3. Wspólna krawędź dwóch powierzchni elementarnych o różnych parametrach i równaniach matematycznych jest zaznaczana na modelu 3D w postaci linii. Linia ta, o ile nie reprezentuje ciągłości G0 między dwoma powierzchniami elementarnymi, jest tylko linią pomocniczą (teoretyczną), niewidoczną na gotowym wyrobie (wyprasce) (rys. 4).

Po otrzymaniu nowych wejściowych cech geometrycznych rozpoczyna się proces aktualizacji odblasku w takiej samej kolejności jak podczas implementowania danych pierwotnych. Konstruktor najpierw analizuje nowe cechy geometryczne pod kątem wykonalności - tak samo jak w początkowej fazie 


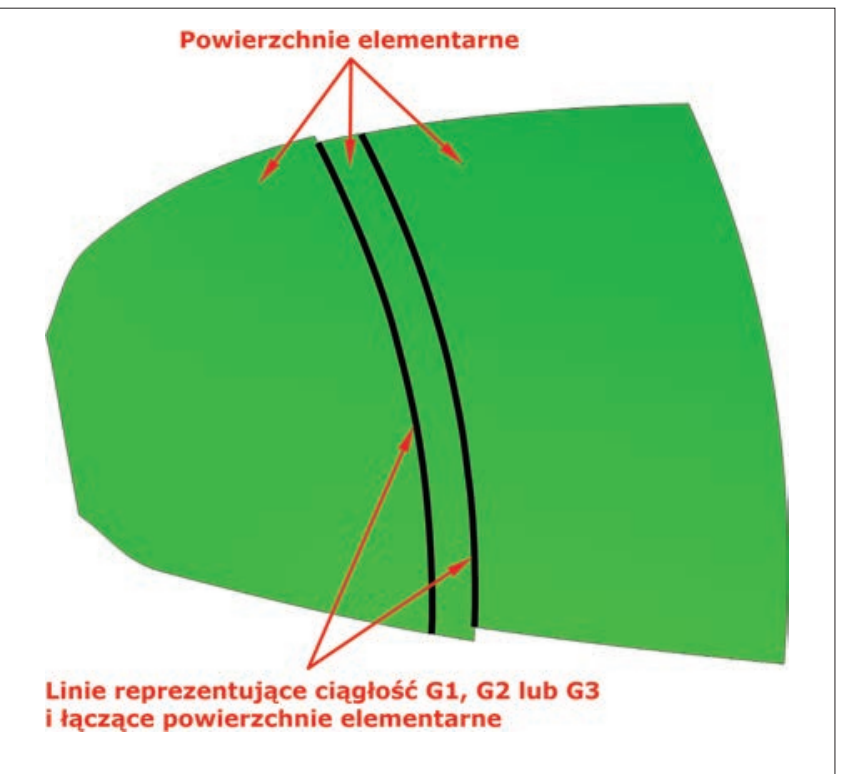

Fig. 4. An exemplary surface derived from the outer lens as a set of interconnected elementary surfaces

Rys. 4. Przykładowa powierzchnia pochodząca od soczewki zewnętrznej jako zestaw wzajemnie powiązanych powierzchni elementarnych

a)

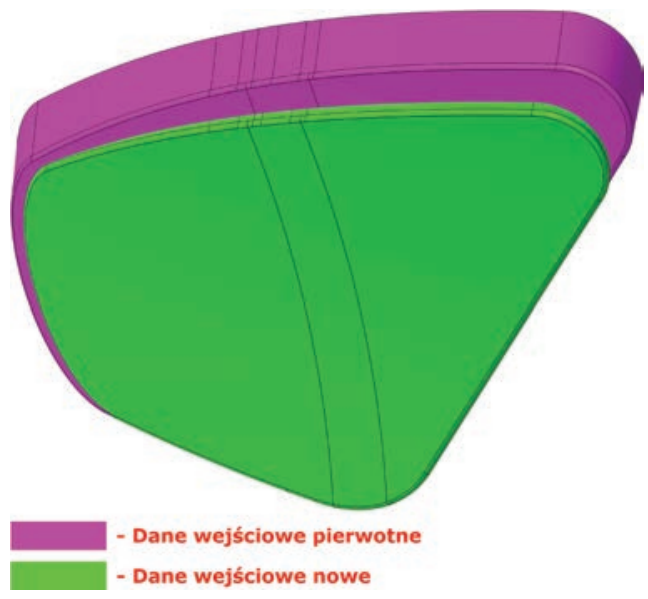

b)
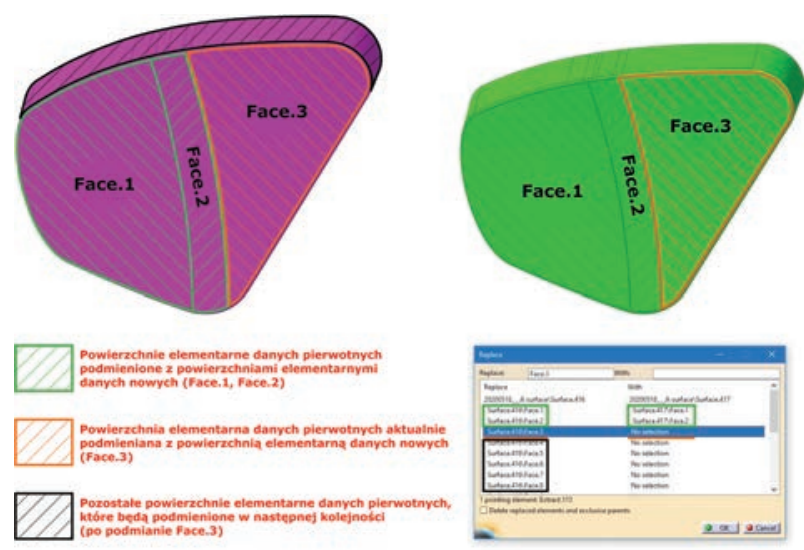

Fig. 5. The process of replacing the surface $A$ of the outer lens: a) comparing the original and new data, $b$ ) replacing the surface $A$ of the lens using the CAx system tool

Rys. 5. Proces podmiany powierzchni $A$ soczewki zewnętrznej: $a$ ) porównanie danych pierwotnych i nowych, $b$ ) podmiana powierzchni $A$ soczewki z użyciem narzędzia systemu CAx projektowania - a następnie przystępuje do podmiany powierzchni $A$ soczewki zewnętrznej. Podmiana zestawu wzajemnie powiązanych powierzchni elementarnych (do których należy powierzchnia $A$ soczewki) polega na podmianie poszczególnych powierzchni elementarnych w tym zestawie (rys. $5 b$ ).

Zaawansowane systemy klasy CAx umożliwiaja podmianę dowolnych elementów struktury modelu 3D. Im więcej danych do podmiany, tym proces aktualizacji jest dłuższy i bardziej pracochłonny. 0 ile w przypadku soczewki zewnętrznej konieczna jest podmiana całej powierzchni $A$, to w przypadku aktualizacji obudowy wcześniejszy, staranny dobór minimalnej ilości danych wejściowych przyczynia się do szybszego zakończenia procesu aktualizacji całego odblasku.

Po aktualizacji soczewki zewnętrznej konstruktor przystępuje do aktualizacji obudowy. Na rys. 6 pokazano porównanie danych wejściowych pierwotnych i nowych, które będą wykorzystane w tym procesie. Idea efektywnego wykorzystania systemów klasy CAx najbardziej ujawnia się właśnie $w$ tej fazie. To w niej optymalna struktura modelu 3D bazującego na innym, wcześniej utworzonym modelu 3D, pozwala

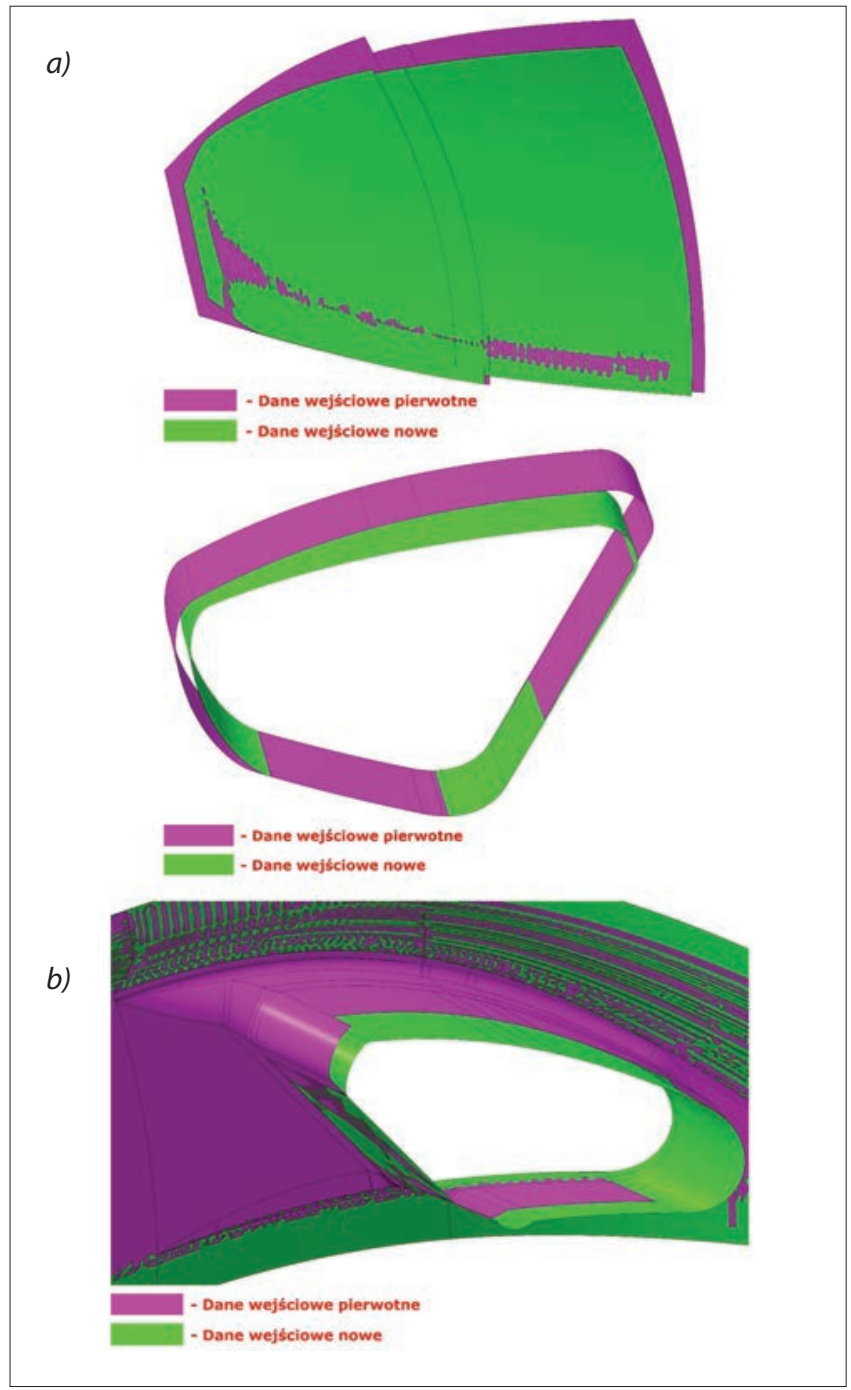

Fig. 6. Primary and new input data: $a$ ) input data from the outer lens, b) input data from the surface $A$ of the bumper

Rys. 6. Porównanie danych wejściowych pierwotnych i nowych: a) dane wejściowe pochodzące od soczewki zewnętrznej, b) dane wejściowe pochodzące od powierzchni $A$ zderzaka 
w zauważalny sposób skrócić proces konstruowania docelowego elementu, a co za tym idzie - w zauważalny sposób wpłynąć na czas i koszty realizacji całego projektu.

Mnogość narzędzi zaawansowanego systemu klasy CAx daje szerokie pole do tworzenia struktury podatnej na łatwą i szybką (relatywnie) modyfikację Jednocześnie mnogość ta wymaga od konstruktora dużej wiedzy i doświadczenia w wykorzystaniu poszczególnych narzędzi i nadawaniu relacji geometrycznych między kolejnymi elementami struktury modelu 3D. Dwa narzędzia o z pozoru takiej samej funkcjonalności inaczej mogą się zachować w różnych rejonach i fazach tworzenia tej struktury. Relacje geometryczne utworzone w jednym fragmencie struktury modelu 3D mogą funkcjonować zupełnie inaczej, a w najgorszym przypadku - nie funkcjonować w innym jej fragmencie.

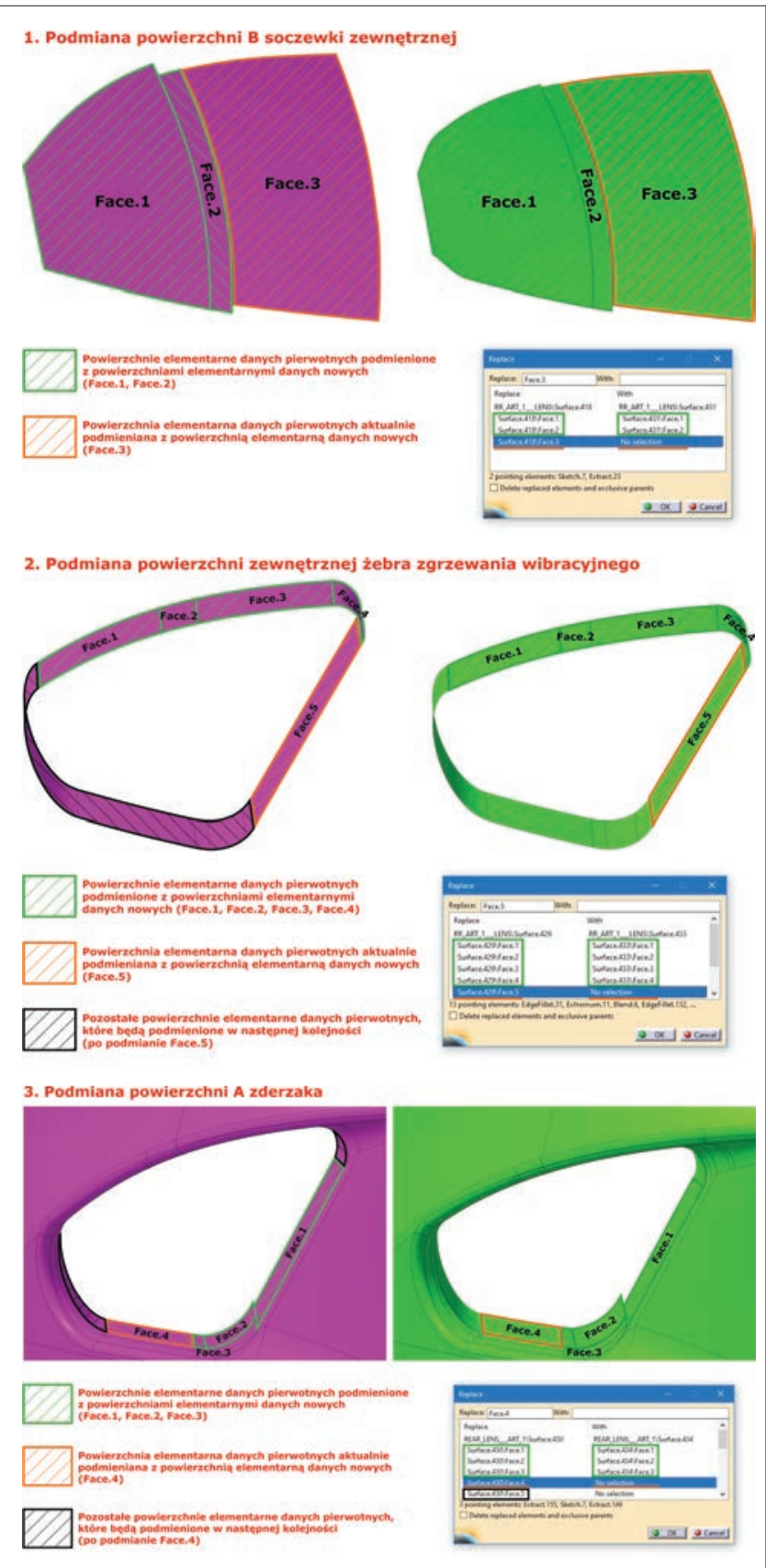

Fig. 7. The process of changing the input data of the reflex lamp housing

Rys. 7. Proces podmiany danych wejściowych obudowy odblasku
Podmiana danych wejściowych obudowy powinna pociągać za sobą aktualizację wszystkich jej elementów składowych, np. żeber dystansujących wzdłuż osi $Y Z$, pinów dystansujących wzdłuż osi $X$ czy klipsów mocujących odblask do zderzaka. Proces podmiany danych wejściowych obudowy pokazano na rys. 7.

Jednak proces podmiany geometrycznych danych wejściowych to dopiero początek aktualizacji modelu 3D obudowy. Po podmianie najważniejszą rolę zaczyna odgrywać wspomniana $\mathrm{w}$ poprzednim rozdziale zawartość drzewa struktury powierzchniowej. Ponieważ podmienione powierzchnie stanowią podstawę dla całej struktury modelu 3D, zaraz po ich podmianie system diagnostyczny systemu (działający w tle) zgłasza konieczność jej aktualizacji. Objawia się to zmianą koloru modelu 3D na czerwony (rys. 8a) oraz dodatkową ikoną przy każdej operacji struktury powierzchniowej i bryłowej (rys. 8b).

Konstruktor przystępuje zatem do aktualizacji zawartości drzewa struktury powierzchniowej. Uporządkowanie, przejrzystość i odpowiednie wykorzystanie narzędzi systemu CAx w strukturze modelu 3D składają się na jego optymalizację i bezproblemowy proces aktualizacji. Na uporządkowanie i przejrzystość wpływa m.in. nazewnictwo poszczególnych zbiorów operacji struktury drzewa. Zbiory te powinny mieć nazwy charakterystyczne dla ich zawartości, tak by rozpoznanie i odszukanie rejonu struktury, który jest przedmiotem zmian/aktualizacji przez konstruktora, było jak najłatwiejsze. Struktura drzewa z pozostawionymi domyślnymi (systemowymi) nazwami

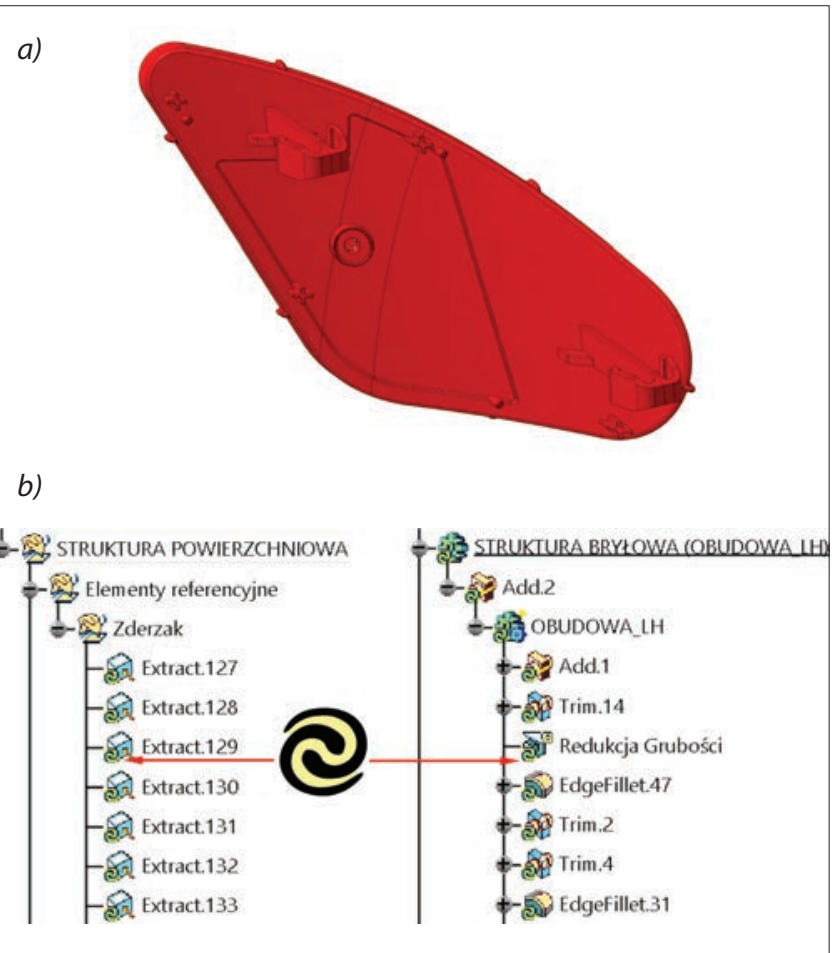

Fig. 8. Result of an input geometric data replacement before procedure of 3D model update: $a$ ) changed color of the 3D model suggesting its non-updated state, $b$ ) fragment of surface and solid structure tree with an update icon

Rys. 8. Rezultat podmiany geometrycznych danych wejściowych przed przystąpieniem do aktualizacji modelu 3D: a) zmieniony kolor modelu 3D sugerujący jego niezaktualizowany stan, $b$ ) fragment drzewa struktury powierzchniowej i bryłowej z ikoną aktualizacji 
zbiorów operacji staje się nieczytelna, a więc przedłuża czas potrzebny na zaktualizowanie modelu 3D.

Przemyślana organizacja struktury poszczególnych rejonów modelu 3D pomaga konstruktorowi kontrolować przebieg aktualizacji. Użycie podstawowych narzędzi, mimo że powiększają one samą strukturę, redukuje możliwość wystąpienia błędów zgłaszanych przez system diagnostyczny, spowodowanych podmianą geometrycznych danych wejściowych. 0 ile zaawansowane systemy klasy CAx oferują złożone narzędzia umożliwiające wygenerowanie geometrii o w zasadzie nieograniczonym kształcie (pod względem złożoności), o tyle ich zastosowanie, wraz ze wzrostem geometrycznego skomplikowania modelu 3D, traci na wadze. Paradoksalnie, pożądane jest stosowanie narzędzi podstawowych, które podczas aktualizacji zawartości drzewa struktury modelu są najbardziej stabilne i jednocześnie łatwe do aktualizacji (rys. 9).

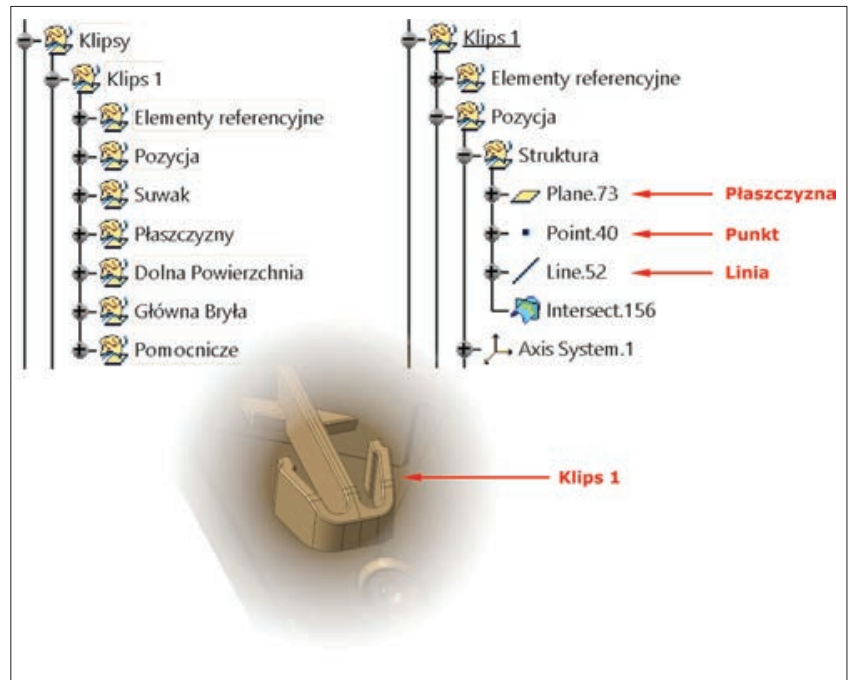

Fig. 9. Organization of the content of the surface structure tree of clip 1 facilitating orientation in the structure (basic CAx system tools, ex.: point, line or plane)

Rys. 9. Organizacja zawartości drzewa struktury powierzchniowe klipsa 1 obudowy ułatwiająca orientację w strukturze (wykorzystanie podstawowych narzędzi systemu CAx, takich jak punkt, linia czy płaszczyzna)

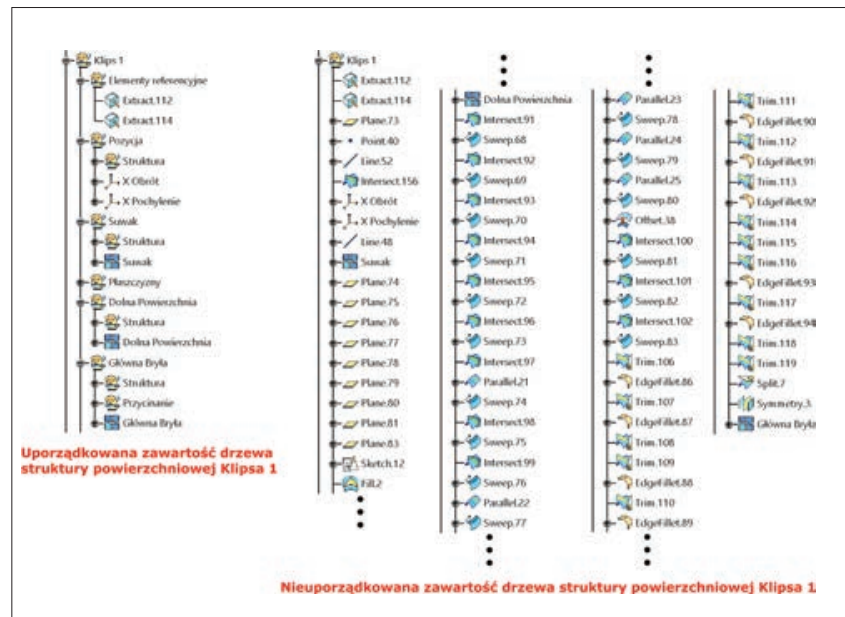

Fig. 10. Comparison between ordered and disordered content of the surface structure tree of clip 1

Rys. 10. Porównanie uporządkowanej i nieuporządkowanej zawartości drzewa struktury powierzchniowej klipsa 1
Na rys. 10 pokazano porównanie wcześniej zaprezentowanej, uporządkowanej struktury jednego z klipsów obudowy z tą samą strukturą klipsa w formie nieuporządkowanej.

$\mathrm{Z}$ kolei na rys. 11 przedstawiono fragment drzewa struktury powierzchniowej w dwóch wariantach. W pierwszym wariancie do utworzenia referencyjnych powierzchni zderzaka użyto podstawowego narzędzia służącego do powielania (kopiowania) istniejących powierzchni pochodzących z wcześniej utworzonej struktury. W drugim wariancie utworzono te same powierzchnie referencyjne co $\mathrm{w}$ pierwszym wariancie, jednak z użyciem zaawansowanego narzędzia, pozwalającego zawrzeć wszystkie składowe w jednej operacji.

Mimo że zastosowanie zaawansowanego narzędzia do powielania istniejących elementów zauważalnie skraca zawartość drzewa struktury powierzchniowej, a więc wpływa na jej prostotę i uporządkowanie, nie oznacza to jednak, że jest to rozwiązanie optymalne. Przy optymalizacji modelu 3D kluczowa jest łatwość i podatność zawartości drzewa struktury na wprowadzanie zmian i aktualizacji. W tym przypadku podstawowe narzędzie do powielania powierzchni wykazuje zdecydowanie większą stabilność i ułatwia aktualizację struktury powierzchniowej.

Można więc wywnioskować, że użycie podstawowych narzędzi systemu CAx przy tworzeniu skomplikowanych geometrycznie modeli 3D znacząco przyczynia się do ich optymalizacji, jednak zauważalnie wpływa na skomplikowanie i wielkość zawartości drzewa (w porównaniu z zastosowaniem narzędzi zawansowanych). Zatem nacisk na dobrą organizację i uporządkowanie zawartości drzewa struktury modeli 3D powinien

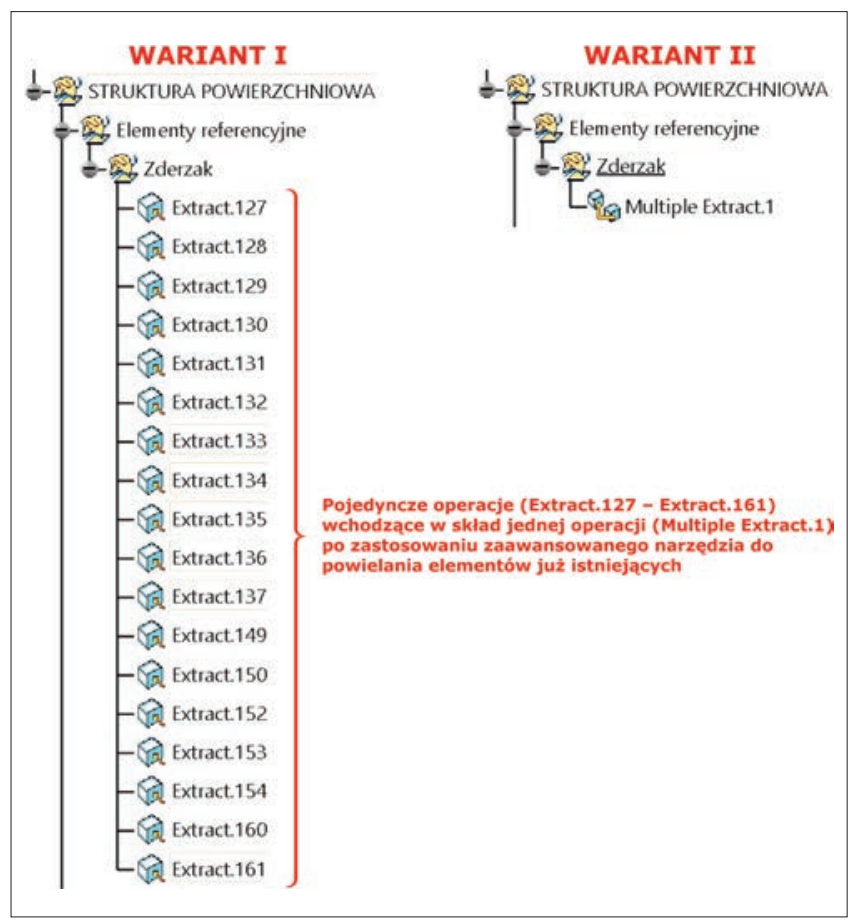

Fig. 11. Comparison of two variants of the surface structure tree: using the basic tool for duplicating existing elements (VARIANT I) and using the advanced tool for duplicating existing elements (VARIANT II) Rys. 11. Porównanie dwóch wariantów drzewa struktury powierzchniowej: z zastosowaniem podstawowego narzędzia do powielania istniejących elementów (WARIANT I) i z zastosowaniem zaawansowanego narzędzia do powielania istniejących elementów (WARIANT II) 


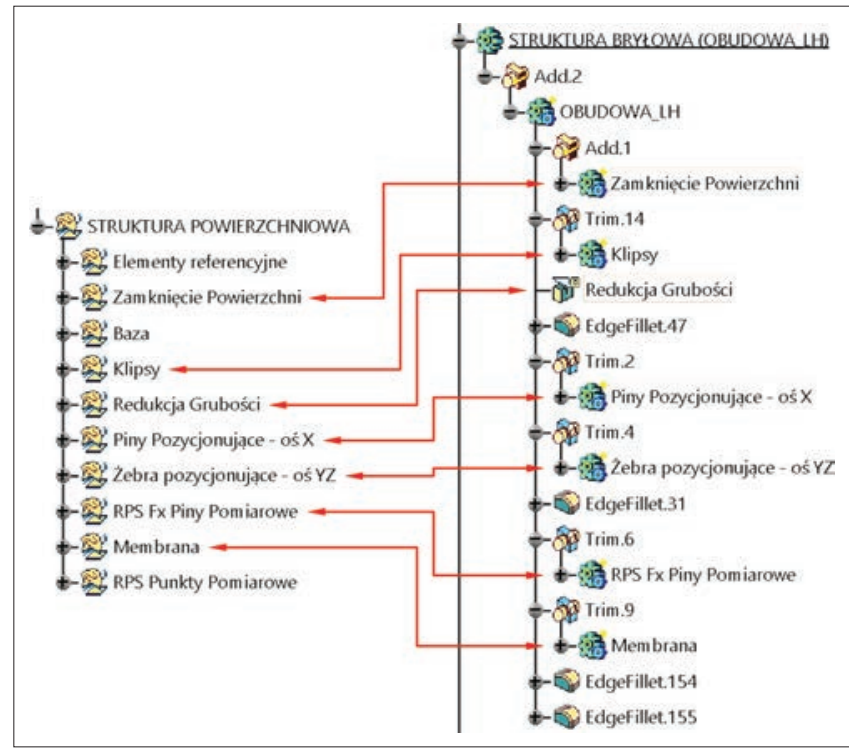

Fig. 12. The overlapping chronology of the structure of the surface and solid trees

Rys. 12. Pokrywająca się chronologia struktury drzewa powierzchniowego i bryłowego

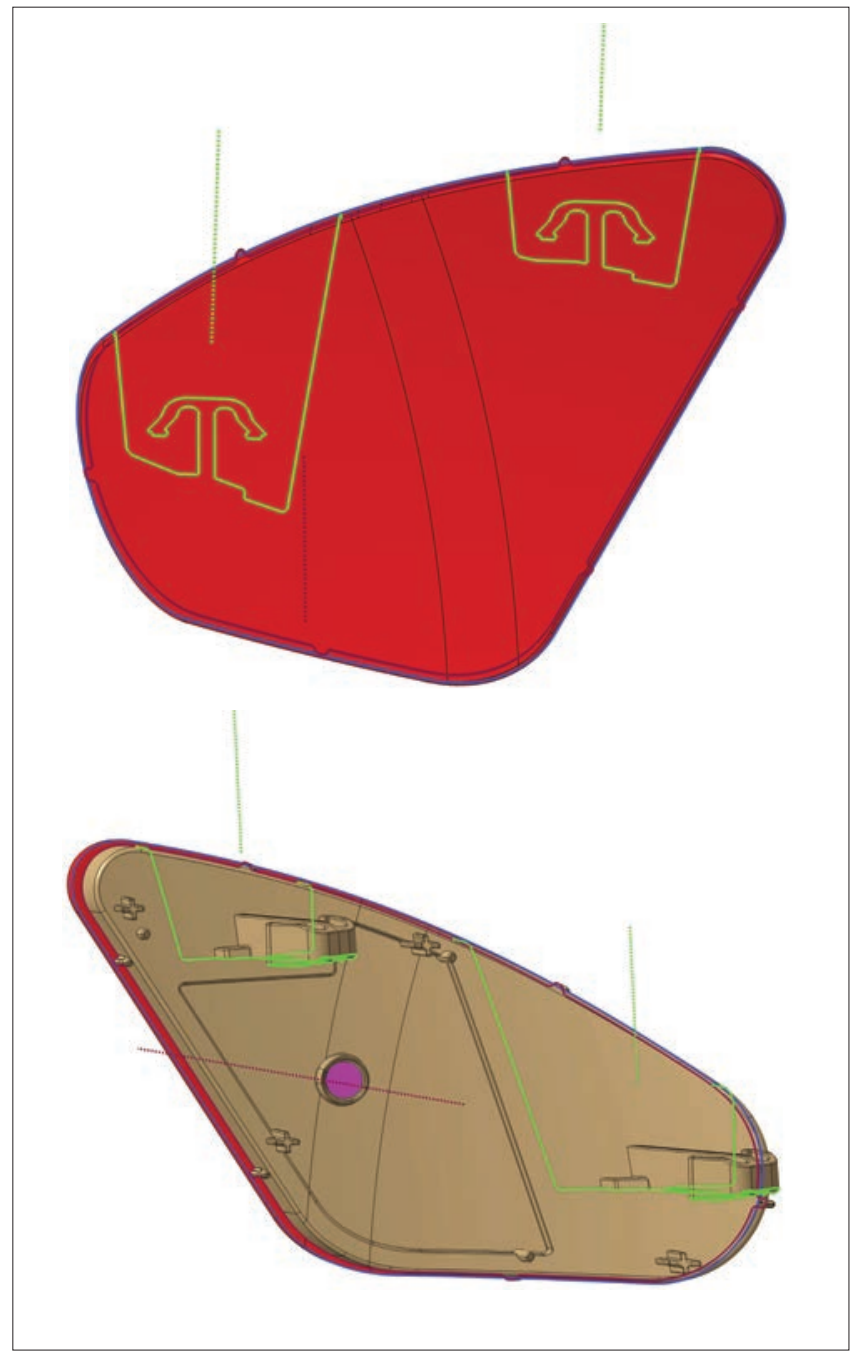

Fig. 13. Updated rear car reflex lamp with marked line of dividing the mold (for each element), lines of dividing the sliders and the direction of opening the mold (for each element) and directions of movement of the sliders

Rys. 13. Zaktualizowany odblask tylny z zaznaczoną linią podziału formy (dla każdego elementu), liniami podziału suwaków oraz kierunkiem otwierania formy (dla każdego elementu) i kierunkami ruchu suwaków

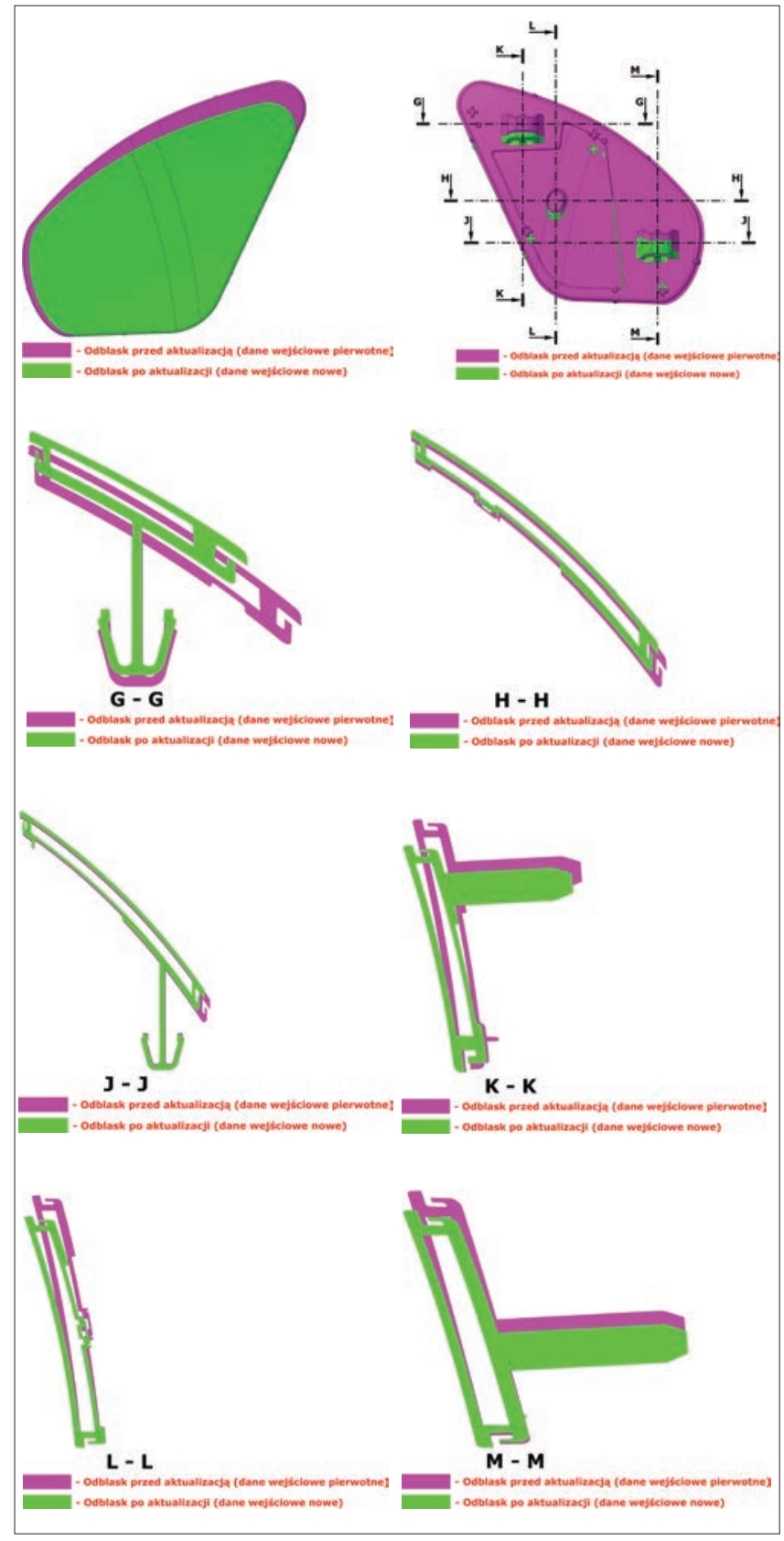

Fig. 14. Comparison of the updated state (green) with the original state (pink)

Rys. 14. Porównanie stanu zaktualizowanego (kolor zielony) ze stanem pierwotnym (kolor różowy)

być jak największy, tak aby niezależnie od stopnia jej skomplikowania zachowywała ona przejrzystość i zapewniała swobodę podczas nawigacji po niej.

Po ukończeniu aktualizacji struktury powierzchniowej konstruktor przystępuje do aktualizacji jej bryłowej odpowiedniczki, która również powinna być utworzona $\mathrm{z}$ zachowaniem wymienionych cech procesu optymalizacji. Zaleca się, aby chronologia zawartości drzewa struktury bryłowej jak najwierniej odzwierciedlała chronologię zawartości drzewa struktury powierzchniowej (rys. 12).

Zaktualizowany odblask i porównanie z jego pierwotnym stanem pokazano na rys. 13 i 14 . Następnie model 3D zostaje wysłany do odbiorcy w celu aktualizacji zderzaka, gdzie - tak jak na wcześniejszym etapie, staje się on daną wejściową do modelu 3D zderzaka. 


\section{Wnioski}

Tworzenie elementów z tworzywa sztucznego w przemyśle motoryzacyjnym to skomplikowany proces obejmujący wiele zagadnień z zakresu inżynierii materiałowej, mechanicznej i wytrzymałościowej. W opisywanym przykładzie należałoby do tego zakresu dodać takie dziedziny, jak optyka, elektronika czy termika. Każdą z nich zajmuje się inna osoba - inżynier i wszystkie one składają się na wspólny rezultat $\mathrm{w}$ postaci gotowego wyrobu spełniającego wymogi klienta i prawne. Bazą tych zagadnień i dziedzin staje się wirtualny model 3D stanowiący podstawę i fundament pomyślnie zrealizowanego projektu.

Ponieważ tworzenie modelu 3D jest najbardziej praco- i czasochłonnym etapem projektowania konstrukcji, można się pokusić o wniosek, że istnieje szerokie pole do optymalizacji tego etapu, a co za tym idzie - możliwość zauważalnego wpływu na przebieg całego projektu, jeśli skupi się tylko na tym jednym elemencie.

W opinii autorów proces tworzenia struktury modelu 3D należałoby przyrównać do procesu tworzenia programu komputerowego, w którym programista dąży do uzyskania jak najprostszej, a w rezultacie optymalnej struktury programu. Język programowania w środowisku konstruktora jest niczym innym jak konkretnym systemem klasy CAx. Komendy programistyczne to poszczególne narzędzia systemu klasy $\mathrm{CAx}$, natomiast struktura programu odzwierciedla drzewo struktury modelu 3D.

Zaprezentowany proces tworzenia samochodowego odblasku tylnego jest przykładem wykorzystania zaawansowanych systemów klasy CAx do projektowania elementów wykonanych z tworzywa sztucznego w przemyśle motoryzacyjnym. Nie znaczy to jednak, że efektywne wykorzystanie systemów klasy CAx odnosi się tylko do tej jednej technologii wytwarzania i gałęzi przemysłu. Z uwagi na stopień skomplikowania pod względem kształtu, jaki mogą przybierać elementy wykonane $\mathrm{z}$ tworzywa sztucznego, sposób tworzenia samej struktury modeli 3D jest szczególnie istotny. Jednak proces projektowania elementów wykonywanych w innych niż zaprezentowana technologiach wytwarzania i dla innych gałęzi przemysłu może być optymalizowany w taki sam sposób. Zoptymalizowana struktura modelu 3D daje konstruktorowi i całemu zespołowi projektowemu poczucie pewności i swobody w poszukiwaniu nowych rozwiązań konstrukcyjnych oraz przyczynia się do przesuwania i poszerzania granicy wykonalności i technologiczności produkcyjnej.

\section{LITERATURA:}

[1] Świaczny G., Wyleżoł M. "Improving the topology of CAD models in the context of their susceptibility to design changes - model preparation stage. Part 1". Mechanik. 8-9 (2020): 53-59, DOI: https://doi.org/10.17814/mechanik.2020.8-9.16.

[2] Wełyczko A. „CATIA v5 Sztuka modelowania powierzchniowego". Gliwice: Wydawnictwo Helion, 2010. 